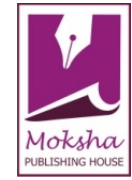

\author{
Review Article \\ www.ijrap.net
}

\title{
A CONCEPTUAL STUDY ON EFFECT OF GUDUCHYADI KWATHA IN THE MANAGEMENT OF AMLAPITTA
}

Paghdar Mohit P. ${ }^{1 *}$, Patel Dhananjay V. ${ }^{2}$

${ }^{1}$ P.G.Scholar, Department of Kayachikitsa, Government Akhandanad Ayurved College, Ahmedabad, Gujarat, India

${ }^{2}$ Assistant. Professor, Department of Kayachikitsa, Government Akhandanad Ayurved College, Ahmedabad, Gujarat, India

Received on: 18/03/16 Revised on: 08/04/16 Accepted on: 12/05/16

\author{
*Corresponding author \\ E-mail: dr.mppaghdar273@gmail.com
}

DOI: $10.7897 / 2277-4343.073102$

\begin{abstract}
The Amlapitta is one of the most common gastro intestinal problems found in the society. Though it is not a big life threatening issue, however runs long time if treated symptomatically. The allopathic physicians used to treat the disease with antacid medicament, which is only symptomatic, not the curative. So the proper solution is still awaited. Ayurvedic management can answer with its own principals of Dosha, Dushya, Srotas, Agni etc. Here the attempt made to find the safe and curative remedy for Amlapitta, in form of Guduchyadi Kwatha.
\end{abstract}

Key words: Amlapitta, Acid Reflux Syndrome, Guduchyadi Kwatha, Gastric diseases.

\section{INTRODUCTION}

Amlapitta can be correlated with Acid Reflux Syndrome which comprises of various types of Gastro-oesophageal Reflux Diseases like Gastritis, Dyspepsia, Heartburn, Hyperacidity, Hypoacidity etc. described in modern sciences. Sixty percent of the adult population will experience some type of gastroesophageal reflux disease (GERD) within a 12 month period and 20 to $30 \%$ will have weekly symptoms. Fifty percent of all people questioned regarding GERD symptoms report that they have more heartburn at night than in the day. Sixty-three percent reported difficulty sleeping and $40 \%$ reported that daily functioning was compromised the next day. ${ }^{1}$

\section{Need of study}

Ayurveda is as old as human civilization based on two principles as maintaining Swaasthya of the Swastha Vyakti and curing the Vikara of the Aatura. From stone- age to space age food pattern of people has undergone numerous changes. ${ }^{2}$

In 21st century, Man is unable to follow Dinacharya and Ritucharya, because of fast life style has made man restless to achieve his unlimited desires in a very short period of time. These desires produce different types of anxiety, worry, anger, fear and depression which directly or indirectly lead to various types of gastrointestinal tract disorders.

Nowadays, he is also attracted towards fast food, junk food, instant and processed food which disturbs the gastro intestinal physiology. Even in Varsha Ritu which aggravates the "Pitta" dosha naturally, he/she consumes aforesaid food which disturbs the balance of Tridosha.

A survey of people suffering from acid peptic diseases in India revealed that it is a very common disease affecting almost all the human being in more or less severity. However the antacids are among the one of the most widely used medicine all over the world. ${ }^{3}$ By taking antacids may cause dose-dependent rebound hyperacidity and milk-alkali syndrome. Antacids that contain aluminum hydroxide may cause constipation, aluminumintoxication, osteomalacia, and hypophosphatemia. ${ }^{4}$

From Ayurvedic point of view, Amlapitta can be treated with Guduchyadi Kwath are commended by Bhaisajya Ratnavali without any harmful effect of drugs.

\section{Aims}

To evaluate the efficacy of Guduchyadi Kwathain the management of Amlapitta.

\section{Diseases Review}

Amlapitta was not considered as a separate disease entity in any of the three old treatise of Ayurveda but it was mentioned as a symptom in a good number of places by Acharya Charaka. Acharya Charaka says in the Samprapti of Amlapitta described as Aamvisha when get mixed with Pitta, the disease Amlapitta develops. Amalpitta is composed of word Amla and Pitta. ${ }^{5}$

Acharya Kashyapa was the first to give a detailed description of the disease and to analyse it on Doshik basis ${ }^{6}$, whereas Madhavakara goes into the details of the disease including classification of the same according to Gati i.e. Urdhvaga and Adhoga Amlapitta. ${ }^{7}$

Nidana of Amlapitta

Aharja Hetu: Viruddha Bhojana, Sandusta Bhojana,Vidahi Bhojana, Vidagdh Bhojana. ${ }^{8}$

Viharaj Hetu: Divaswapana, Atisnana and Avagahana ${ }^{9}$

Manasika Hetu : Kama, Krudha, Lobha, Moha, Irshya, Shoka, Bhaya $^{10}$

Purvarupa of Amlapitta: Acharya Charaka has mentioned some Purvarupa of Grahani like Trishna, Alasya, loss of Bala, Annavidaha, Gauravata etc. These symptoms may be considered as the Purvarupa of Amlapitta. ${ }^{11}$ 
Rupas (Symptoms and Signs) of Amlapitta

Avipaka, Klama, Utklesha, Tikta/Amla Udgara, Guarav, HridKantha Daha, Aruchi. ${ }^{12}$

Samprapti of Amlapitta

According to Acharya Kashaypa, indulgence of Nidana causes, the Dosha prakopa especially of Pitta Dosh. This Dosha Prakopa creates Mandagni, and due to Mandagni ingested food becomes Vidagdha and Shuktibhava. This Vidagdha and Shuktbhava of food create Amlata in Amashaya. This condition is called Amlapitta. $^{13}$

\section{Treatment of Amlapitta}

As per Ayurveda line of treatment for Amlapitta is given drugs which are Tikta Rasa dominant and Pachana property. ${ }^{14}$

\section{Drug Review}

Guduchyadi Kwatha: it is recommended in Bhaisajya Ratnavali for the Amlapitta. ${ }^{15}$

\begin{tabular}{|c|c|c|}
\hline Name of Drug & Latin Name & Proportion \\
\hline Guduchi & Tinospora Cordifolia & 1 part \\
\hline Khadir & Acacia Catechu & 1 part \\
\hline Yastimadhu & Glycyrrhiza Glabra & 1 part \\
\hline Daruharidra & Berberis Aristata & 1 part \\
\hline Sugandhabala & Pavonia Odorata & 1 part \\
\hline Draksha & Vitis Vinifera & 1 part \\
\hline Haritaki & Terminalia Chebula & 1 part \\
\hline
\end{tabular}

The contains like Guduchi ${ }^{16}$, Yastimadhu ${ }^{18}$, Draksha ${ }^{21}$ and Sugandhabala $^{20}$ are well known Dahashamaka drugs which helps in controlling Daha (Hriddaha \& Kanthadaha) of Amlapitta.

Madhura Vipaka of Guduchi ${ }^{16}$, Yastimadhu ${ }^{18}$ and Draksha ${ }^{21}$ and Shita Virya of Yastimadhu ${ }^{18}$, Draksha ${ }^{21}$, Sugandhabala ${ }^{20}$, Haritaki $^{22}$ and Khadir $^{17}$ help in relieving Amlodgara and Tiktodgara.

Guduchi $^{16}$, Daruharidra ${ }^{19}$, Sugandhabala ${ }^{20}$ and Haritaki ${ }^{22}$ help in improving Mandagni and Aruchi through their Dipana-Pachana karma. Dipana-Pachana increases Jatharagni due to which there is less chance of Avipaka and so there is reduction in symptoms like Utklesha and Udara Gaurava.

Daruharidra $^{19}$, Sugandhabala ${ }^{20}$ and Haritaki $^{22}$ are also Amapachaka drugs which help in digesting Aama produced due to Mandagni. Moreover, they have also Yakruduttejaka property which improves the functions of liver (Moola of Raktavaha srotasa). Thus Rasa-Raktavaha srotodusti can be treated very well.

Chhardi Nigrahana and Trushna Nigrahana property ofGuduchi $^{16}$, Yastimadhu ${ }^{18}$, Draksha ${ }^{21}$ and Sugandhabala ${ }^{17}$ relieves Chhardi and Trushna in Amlapitta. Guduchi ${ }^{16}$, Yastimadhu $^{18}$, Sugandhabala ${ }^{20}$, Draksha ${ }^{21}$ and Haritaki ${ }^{22}$ help in relieving Adhmana through their Anulomaka property.

Guduchi $^{16}$, Daruharidra ${ }^{19}$ and Haritaki ${ }^{22}$ are Ushna Virya drugs which do not allow Vata Prakopa and so there is no Adhmana. Yastimadhu $^{18}$ and Haritaki ${ }^{22}$ are also Mrudu-Rechana drugs which controls Vibandha.

Guduchi $^{16}$, Yastimadhu ${ }^{18}$ and Haritaki ${ }^{22}$ are Rasayana drugs through which all Dhatus get adequate nourishment and thus Dhatu-Prasadana is occured.

Rakta-shodhaka and Vrana-shodhana andRopana, Varnya, Kandughna, Kusthaghna and Krimighna properties of some drugs helps in subsiding the Upadravas like Pandu, Vicharchika, Kandu, Kotha, etc.

Thus from the ingredients described above, it can be stated that all the Dravyas used in the combination "Guduchyadi Kwatha" are effective over all the conditions described in Amlapitta.

\section{Pathya- Apathya:}

Pathya Ahara: Purana Shali, Mudga, Masura, Harenuk, Goghrita, Go-dugdha Jangala mansa, Kalay shaka. ${ }^{23}$

Pathya Vihara: Samuchitvyayam, Deshantara gamana. ${ }^{23}$

Apathya Ahara: Masha, Kulattha, Dadhi Lavana Rasa Amla Rasa Katu Rasa. ${ }^{24}$

Apathya Vihara: Vegavidharana ${ }^{24}$

This way, Guduchyadi Kwatha will help to break the etiopathology of Tamakshwasa.

\section{DISCUSSION}

Amlapitta is a very common disease that everyone usually suffers once in the life.

Probable Mode of action of Guduchyadi Kwatha on Amlapitta

Dosha: Majority of the drugs have Tikta-Madhura Rasa, Laghu-Ruksha Guna, Shita Virya, Madhura Vipaka and PittaKaphaghna properties which alleviates the Pitta dosha, the aggravating factor of Amlapitta. ${ }^{25}$

Dushya: Most of the drugs have Dipana-Pachana property which acts directly on Agni, thus increasing Jatharagni and Dhatvagni. Increased Dhatvagni stop the process of vitiation of Rasa and Raktadhatu which are the main dushyas of Amlapitta. Some of the drugs also possess Rochana, Anulomana, Raktashodhana and Krimighna properties which are essential to treat Rasa-Raktadusti.

Agni and Ama: Mandagni is the motive cause for the disease Amlapitta. As a result, Ama is produced. Dipana-Pachana property of most of the drugs corrects the Mandagni ${ }^{13}$ and breaks the pathogenesis of Amlapitta ${ }^{26}$. It also has Amapachana property. Hence it promotes Dhatvagni and as a result Dhatupusti process is motivated.

Srotasa: Most of the drugs possess Laghu-RukshaGuna and Tikta-Madhura-KashayaRasa which purifies the Srotasa through their srotoshuddhikara properties ${ }^{26}$.

\section{CONCLUSION}

Hence it can be concluded that Guduchyadi Kwatha can be considered as very useful and effective Ayurvedic combination in the management of Amlapitta.

\section{REFERENCES}

1. Homepage/Web site www.healthline.com Acid Reflux (GERD) Statistics and Facts available from: http://www.healthline.com/health/gerd/statistics, cited 2016 March 08.

2. Agnivesha, Charaka, Dridhabala, K Shastri and G Chaturvedi, Charaka Samhita, Vidyotini Hindi Commentary, Sutra Sthana, 30/26, Chaukhambha Bharati Academy, Varanasi, Reprint: 2013, p.587.

3. A Clinical Study of Guduchyadi Compound in The Management of Amlapitta.by Rina Purani S. in 2008.

4. Homepage/Web site www.rxlist.com antacids available from:http://www.rxlist.com/antacids-page5/drugscondition.htm cited 2016 March 10. 
5. Charak, V Shukla, Charaka Samhita, Vaidya Manorama Hindi Commentary, Chikitsasthan 15/44, Chaukhambha Sanskrit Prakashan, Delhi, Vol-2, Reprint: 2010, p.367.

6. Kasyapa, Kasyapa Samhita, S Bhisagacharya, Khilsthan 16/1, Chaukhambha Sanskrit Sansthan, Varanasi, Reprint: 2012, p.335.

7. Madhukosha, Madhav Nidana, R J Parikh, Ch.51/3-6, Sastu Sahitya Vardhak Karyalaya, Ahmedabad, Reprint: 2003, p.668-669.

8. Madhukosha, Madhav Nidana, R J Parikh, Ch.51/1, Sastu Sahitya Vardhak Karyalaya, Ahmedabad, Reprint: 2003, p.667.

9. Kasyapa, Kasyapa Samhita, S Bhisagacharya, Khilsthan 16/6, Chaukhambha Sanskrit Sansthan, Varanasi, Reprint: 2012 , p.335.

10. Comparative Study of Eladi Churna and Avipattikara Churna In The Management of Amlapitta, Neha Joshi: 2013.

11. Charak, V Shukla, Charaka Samhita, Vaidya Manorama Hindi Commentary, Chikitsasthan $15 / 55$, Chaukhambha Sanskrit Prakashan, Delhi, Vol-2, Reprint : 2010, p.369.

12. Madhukosha, Madhavnidana, R J Parikh, Ch.51/2, Sastu Sahitya Vardhak Karyalaya, Ahmedabad, Reprint: 2003, p.668.

13. Kasyapa, Kasyapa Samhita, S Bhisagacharya, Khilsthan 16/7-8, Chaukhambha Sanskrit Sansthan, Varanasi, Reprint: 2012, p.336.

14. Yogaratnakara, B Sastri, Utradh. Amlapittadhikar, Chaukhambha Prakashan, Varanasi. Reprint: 2013, p.239.

15. Bhaisjya Ratnavali, A Shastri, 56/16, ChaukhambhaPrakasan, Varanasi, Reprint: 2011, p.921.

16. B Misra, Bhavaprakasa Nighantu, Guduchyadi Varga, Guduchi, 1-10, Chaukhambha Sanskrit Bhavan, Varanasi, Vol-1, Reprint: 2013, p.269.

17. B Misra, Bhavaprakasa Nighantu, Vatadi Varga, Khadir, 3031, Chaukhambha Sanskrit Bhavan, Varanasi, Vol-1, Reprint: 2013, p.525.
18. B Misra, Bhavaprakasa Nighantu, Haritakyadi Varga Yastimadhu, 145-146, Chaukhambha Sanskrit Bhavan, Varanasi, Vol-1, Reprint: 2013, p.65.

19. B Misra, Bhavaprakasa Nighantu, Haritakyadi Varga, Daruharidra, 200-202, Chaukhambha Sanskrit Bhavan, Varanasi, Vol-1, Reprint: 2013, p. 118.

20. B Misra, Bhavaprakasa Nighantu, Karpuradi Varga, Sugandhabala, 82-83, Chaukhambha Sanskrit Bhavan, Varanasi, Vol-1, Reprint: 2013, p. 237.

21. B Misra, Bhavaprakasa Nighantu, Aamradiphala Varga, Draksha, 109-113, Chaukhambha Sanskrit Bhavan, Varanasi, Vol-1, Reprint: 2013, p. 585.

22. B Misra, Bhavaprakasa Nighantu, Haritakyadi Varga, Haritaki, 19-22, Chaukhambha Sanskrit Bhavan, Varanasi, Vol-1, Reprint: 2013, p. 05.

23. Kasyapa, Kasyapa Samhita, S Bhisagacharya, Khilsthan, 16/38-41, Chaukhambha Sanskrit Sansthan, Varanasi, Reprint: 2012, p. 338.

24. Yogaratnakara, B Sastri, Utradh. Amlapittadhikar, Chaukhambha Prakashan, Varanasi. Reprint: 2013, p. 244.

25. Madhukosha, Madhavnidana, R J Parikh, Ch.51/1, Sastu Sahitya Vardhak Karyalaya, Ahmedabad, Reprint: 2003, p. 668.

26. Agnivesha, Charaka, Dridhabala, K Shastri and G Chaturvedi, Charaka Samhita, Vidyotini Hindi Commentary, Sutra Sthana $1 / 65$, Chaukhambha Bharati Academy, Varanasi, Reprint: 2013, p. 39.

\section{Cite this article as:}

Paghdar Mohit P., Patel Dhananjay V. A conceptual study on effect of guduchyadi kwatha in the management of amlapitta. Int. J. Res. Ayurveda Pharm. May - Jun 2016;7(3): 13-15 http://dx.doi.org/10.7897/2277-4343.073102

\section{Source of support: Nil, Conflict of interest: None Declared}

Disclaimer: IJRAP is solely owned by Moksha Publishing House - A non-profit publishing house, dedicated to publish quality research, while every effort has been taken to verify the accuracy of the content published in our Journal. IJRAP cannot accept any responsibility or liability for the site content and articles published. The views expressed in articles by our contributing authors are not necessarily those of IJRAP editor or editorial board members. 